\title{
E-Readiness Evaluation of High School Student Biology Learning During the Covid-19 Pandemic
}

\author{
Jamaluddin ${ }^{1,2 *}$, A. Wahab Jufri1,2, \& Agus Ramdani ${ }^{1,2}$ \\ ${ }^{1}$ Biology Education Study Program, Teacher Training and Education Faculty, University of Mataram, Mataram, Lombok, West \\ Nusatenggara, Indonesia. \\ ${ }^{1}$ Master Science Education Program, Postgraduate Program, University of Mataram, Mataram, Lombok, West Nusatenggara, Indonesia.
}

\section{DOI: $\underline{10.29303 / \text { jppipa.v7iSpeciallssue.1017 }}$}

\section{Article Info}

Received: August 4th, 2021

Revised: November 25th, 2021

Accepted: November 28th, 2021

\begin{abstract}
E-Readiness is the level of readiness that a person needs to understand and apply information and communication technology. E-Readiness can also be interpreted as readiness to sort, interpret, and process digital knowledge. E-Readiness is very important for students to be able to take part in online learning during the Covid-19 pandemic. The purpose of this study was to describe the level of E-Readiness in learning biology for high school students in West Lombok Regency in participating in online learning of biology subjects. This study uses a quantitative descriptive research method. The instrument used to obtain student E-Readiness data is the E-Readiness questionnaire. Data collection was carried out using a survey technique by distributing questionnaires using the google form application. The number of respondents who filled out the questionnaire was 622 students. Data analysis was carried out using descriptive statistical analysis techniques that refer to the An Integration Information Rich E-Readiness Assessment Tool evaluation model. Data analysis using the evaluation model was carried out on each indicator of the E-readiness segment. The results of data analysis found that: (1) Enterprise E-Readiness segment $79.88 \%$ ready; (2) ICT readiness segment 82.96 ready; (3) Human resources readiness 83.88 ready, 4 . Information readiness segment, $70.72 \%$ ready, and 5 . External environment readiness $84.42 \%$ is ready. From the data analysis, it was found that the EReadiness of studying biology for high school students was 3.1\% Very Unprepared, 16.4\% Unprepared, $54.9 \%$ Ready, and $25.6 \%$ Very Ready. On average $80.5 \%$ of high school students have good skills in using information and communication technology. Thus, it can be concluded that an average of $80.5 \%$ of students' E-Readiness in learning biology had a good level of readiness, and $19.5 \%$ did not yet have a readiness level to participate in online biology learning in West Lombok Regency.
\end{abstract}

Keywords: E-Readiness; Covid-19; Riche-Readiness Assessment Tool; Information Technology

Citation: Jamaluddin, J., Jufri, A. W., \& Ramdhani, A. (2021). E-Readiness Evaluation of High School Student Biology Learning During the Covid-19 Pandemic. Jurnal Penelitian Pendidikan IPA, 7(SpecialIssue), 131-138. https://doi.org/10.29303/jppipa.v7iSpecialIssue.1017

\section{Introduction}

The development of information and communication technology has made a very significant contribution (Djalante et al., 2020) when Indonesia is experiencing the disastrous spread of the Covid-19 pandemic and has had an impact on learning policies at all levels of education. Sohrabi et al., (2020) stated that Covid-19 is an unprecedented outbreak of pneumonia of unknown etiology in Wuhan City, Hubei province in China emerged in December 2019. A new coronavirus was identified as the causative agent and later called

\footnotetext{
*Email: Jamaluddin.fkip@unram.ac.id
} 
COVID -19 by the World Health Organization (WHO) (Laksana, 2021).

The rapid spread of the Covid-19 pandemic is very worrying to have a negative impact on the safety of students, educators, and other school residents (AlHanawi et al., 2020). Face-to-face learning in the classroom will have a high risk of accelerating the transmission of Covid-19 to students (OECD, 2020). So a solution is needed to overcome this problem. Face-toface learning in the classroom will have a high risk of accelerating the transmission of Covid-19 to students, solutions are needed to overcome these problems.

The Ministry of Education and Culture (2020) has issued various policies and initiatives to deal with learning obstacles during the Covid-19 pandemic. The principle of education policy during the Covid-19 pandemic is to prioritize the health and safety of students, educators, education staff, families, and society in general, as well as consider the growth and development of students and psychosocial conditions in an effort to fulfill educational services during the Covid-19 pandemic. To overcome learning problems during the Covid-19 pandemic is to carry out online learning as an alternative that can overcome these problems. Sadikin \& Hamidah (2020), stated that learning must be designed, implemented, and evaluated online. Face-to-face learning in the classroom like before the pandemic must be replaced with an internet-based learning system using learning tools that allow students to learn online.

Syarifudin, (2020) stated that online learning can be done anytime and anywhere without being bound by time and without having to meet face to face. In the current era of information technology development, online learning is increasingly sophisticated with various applications and features that make it easier for users (Sagita \& Khairunnisa, 2020). Not being bound by time and being done without meeting face to face are the advantages of online learning that educators can take advantage of. As is currently the case, online learning is the only form of learning that educators can do when natural disasters or global pandemics such as the Covid-19 pandemic occur. Online learning is the most appropriate choice that can be made by educators so that students can still study from home, and to secure them from the transmission of Covid-19 (Muthuprasad et al., 2021).

The development of information and communication technology has brought enormous changes to the advancement of the world of education. Along with these developments, learning methods have also experienced many developments, both personal learning methods, learning media, or the learning process. The form of the development of information technology that is applied in the world of education is E-learning. Internet-based learning or ELearning is an innovation that has a very large contribution to changes in the learning process, where the learning process is no longer only listening to material descriptions from educators but students also carry out other activities such as observing, doing, demonstrating, and others (Yuhdi \& Amalia, 2018).

The results of research by Ratnawati \& Vivianti, (2020) found that online learning was able to become an alternative learning method to be an appropriate solution and could be implemented during the Covid 19 pandemic so that it did not interfere with learning time and made it easier for students and lecturers to carry out learning. To carry out internet-based learning/E-Learning, it is necessary to support several internet-based learning applications. According to Handarini, \& Wulandari (2020), there are several applications that can help online learning activities, such as WhatsApp, zoom, web blog, Edmodo, and others. The government also takes a role in dealing with inequality in learning activities during the Covid 19 pandemic. Launching the official website of the Indonesian Ministry of Education and Culture, there are 12 platforms or applications that students can access to study at home, namely (1) learning houses; (2) Our table; (3) Icando; (4) Indonesiax; (5) Google for education; (6) Smart class; (7) Microsoft office 365; (8) Quipper school (9) Teacher's room; (10) Your school; (11) Zenius; (12) Cisco Webex.

To be able to take advantage of applications in online learning, students must have the level of knowledge or readiness needed to understand and apply digital information technology called Ereadiness. This ability is very important for students to be able to study biology online during the Covid-19 pandemic. Likewise, the implementation of high school biology learning in West Lombok Regency which is carried out online also requires students' E-readiness. The problem is how the level of E-readiness of SMAN students in West Lombok Regency in participating in online biology learning. Based on these problems, the purpose of this study was to evaluate the level of EReadiness in learning biology for high school students in West Lombok Regency in participating in online biology learning during the Covid-19 pandemic.

\section{Method}

This research is quantitative descriptive research. This study seeks to explain or provide an overview of the E-readiness of learning biology for high school students in West Lombok Regency in participating in online biology learning during the Covid-19 pandemic. The research was conducted in the odd semester and 
even semester of the 2020/2021 academic year. The research sample was determined by purposive sampling technique by considering student responses to the E-readiness questionnaire and the location of SMA on the geographical map of West Lombok Regency. On that basis, it was determined that the students who were the samples of the study were students from SMAN 1 Gerung, SMAN 1 Labuapi, SMAN 1 Narmada, and SMAN 1 Gunungsari. The number of research samples was 622 students of classes $\mathrm{X}, \mathrm{XI}$, and XII.

Data was collected using an E-Readiness questionnaire. The research instrument was adapted from an integration information rich E-Readiness assessment tool by Mutula and Brakel (2006). To obtain information about students' readiness to understand and apply information and communication technology (ICT) in their studies (Hidayat et al., 2018).

This research questionnaire contains 25 statements with alternative answer choices "Unprepared (U)" with a score of 2, "Ready (R)" with a score of 3, "Very Ready (VR)" with a score of 4 . The questionnaire was submitted to students using the google form application through the WA Group of each school's class. The purpose of using a questionnaire in this study was to determine the response of students' readiness to online learning for high school biology subjects in West Lombok Regency. The components in the questionnaire consist of the respondent's identity as well as a number of statements that reveal students' Ereadiness in participating in online biology learning and the obstacles they face while studying biology during the Covid-19 pandemic.

The indicators used to measure students' EReadiness in online biology learning are: (1) Enterprise E-Readiness segment, namely the readiness of students to use information and communication technology in learning; (2) ICT readiness segment is the readiness of infrastructure and internet access; (3) Human resource readiness, namely the readiness of students to use information and communication technology; (4) Information readiness, namely the readiness of students to access digital information; and (5) External environment readiness, namely the readiness of the environment to support students from the use of information and communication technology in learning.

The technique of analyzing the students' EReadiness data was using descriptive statistical analysis techniques. The data analysis is carried out by describing or describing the data that has been collected as it is without intending to make conclusions that apply to the public or generalizations. This analysis is only an accumulation of basic data about students' E-Readiness in the form of a description. The data collected from the questionnaire are grouped in tables, given a percentage, then displayed in the form of a diagram, analyzed, and then described. The evaluation model consists of 5 components of readiness. These components are used as indicators to assess students' E-readiness in learning biology online.

\section{Result and Discussion}

Data obtained from respondents was a number of 622 students. This research questionnaire contains 25 statements with alternative answer choices "Very Unprepared (VU)" with a score of 1, " Unprepared (U)" with a score of 2, "Ready (R)" with a score of 3, "Very Ready (VR)" with a score of 4 . The purpose of using a questionnaire in this study was to determine the response level of students' readiness from each Ereadiness indicator to online high school biology learning in West Lombok Regency. From the data obtained, it was analyzed to determine the level of readiness of high school students in West Lombok in participating in online biology learning. The description of the students' E-readiness data is shown in Table 1.

Table 1. Data on E-readiness of SMAN Students in West Lombok in Participating in Online Biology Learning

\begin{tabular}{|c|c|c|c|c|c|}
\hline No. & Description of Student E-Readiness & $\begin{array}{l}\mathrm{VU} \\
(\%)\end{array}$ & $\begin{array}{c}U \\
(\%)\end{array}$ & $\begin{array}{c}\mathrm{R} \\
(\%) \\
\end{array}$ & $\begin{array}{l}\text { VR } \\
(\%)\end{array}$ \\
\hline 1. & $\begin{array}{l}\text { Readiness to find information related to biological material to be studied } \\
\text { through search engines (Google, Yahoo, etc.) or social media (WhatsApp, } \\
\text { Facebook, etc.) before the lesson begins }\end{array}$ & 1.30 & 8.80 & 63.50 & 26.40 \\
\hline 2. & Prefers to read books on a computer/mobile rather than a textbook & 10.80 & 39.10 & 37.00 & 13.20 \\
\hline 3. & Readiness to use e-learning to complete Biology learning tasks & 2.10 & 11.60 & 61.90 & 24.40 \\
\hline 4. & Readiness to use spare time to study biology with cellphone/tablet/computer & 1.90 & 16.40 & 63.20 & 18.50 \\
\hline 5. & $\begin{array}{l}\text { The ability of parents/guardians to facilitate students with information and } \\
\text { communication technology (computers, laptops, cellphones, etc.) }\end{array}$ & 2.10 & 6.60 & 50.60 & 40.70 \\
\hline 6. & Readiness to search for learning materials/materials via the internet & 1.80 & 5.90 & 57.20 & 35.00 \\
\hline 7. & $\begin{array}{l}\text { Have basic internet readiness (email, searching, download) in accessing biology } \\
\text { subject matter }\end{array}$ & 1.80 & 12.50 & 56.30 & 29.40 \\
\hline 8. & Readiness to use social media to complete school/homework assignments & 3.50 & 18.60 & 48.60 & 29.30 \\
\hline
\end{tabular}




\begin{tabular}{|c|c|c|c|c|c|}
\hline No. & Description of Student E-Readiness & $\begin{array}{l}\text { VU } \\
(\%)\end{array}$ & $\begin{array}{c}\mathrm{U} \\
(\%)\end{array}$ & $\begin{array}{c}\mathrm{R} \\
(\%)\end{array}$ & $\begin{array}{l}\mathrm{VR} \\
(\%)\end{array}$ \\
\hline 9. & Readiness to use online media to help learn Biology & 2.70 & 10.00 & 45.80 & 41.50 \\
\hline 10. & $\begin{array}{l}\text { Readiness to operate basic computer (eg, typing, creating, saving, editing files, } \\
\text { etc.) }\end{array}$ & 5.30 & 23.00 & 48.20 & 23.50 \\
\hline 11. & $\begin{array}{l}\text { Have a cellphone/table/computer that can be used to find information via the } \\
\text { internet or social media }\end{array}$ & 1.00 & 5.90 & 60.60 & 32.50 \\
\hline 12. & Readiness to access information anywhere & 1.30 & 15.80 & 57.10 & 25.90 \\
\hline 13. & $\begin{array}{l}\text { Readiness to follow and update social media and other applications to find } \\
\text { information on the required subject matter }\end{array}$ & 1.60 & 21.40 & 54.50 & 22.50 \\
\hline 14. & $\begin{array}{l}\text { Readiness to rediscover information related to biology lessons that have been } \\
\text { accessed from the internet }\end{array}$ & 1.40 & 14.80 & 66.60 & 17.20 \\
\hline 15. & $\begin{array}{l}\text { Ownership of active information sharing facilities in cyberspace (Facebook, } \\
\text { WhatsApp, blog, etc.) }\end{array}$ & 1.90 & 15.60 & 55.80 & 26.70 \\
\hline 16. & $\begin{array}{l}\text { Ability to use applications from the internet to view videos or simulations } \\
\text { related to biology subject matter }\end{array}$ & 0.60 & 12.20 & 58.70 & 28.50 \\
\hline 17. & Readiness to collect biology subject matter on mobile/tablet/computer & 2.10 & 26.40 & 58.80 & 12.70 \\
\hline 18. & Have biology course material on social media & 2.70 & 24.30 & 59.00 & 14.00 \\
\hline 19. & Readiness to use e-books as a means to study biology & 6.60 & 33.90 & 48.40 & 11.10 \\
\hline 20. & Readiness to provide Biology learning materials from e-books and e-learning & 7.20 & 30.40 & 50.20 & 12.20 \\
\hline 21. & $\begin{array}{l}\text { Have sufficient electricity network to be used to access information around home } \\
\text { and school }\end{array}$ & 3.20 & 15.90 & 56.80 & 24.10 \\
\hline 22. & $\begin{array}{l}\text { Readiness of educators to use social media in providing information about the } \\
\text { subject matter }\end{array}$ & 0.80 & 5.50 & 58.70 & 35.00 \\
\hline 23. & Utilization of ICT for Biology learning activities & 2.10 & 10.10 & 63.50 & 24.30 \\
\hline 24. & The school provides internet access in the school environment & 3.50 & 10.50 & 43.70 & 42.30 \\
\hline \multirow[t]{2}{*}{25.} & Internet access speed is good & 6.10 & 20.10 & 47.70 & 26.00 \\
\hline & Average Student E-readiness & 3.10 & 16.40 & 54.90 & 25.60 \\
\hline
\end{tabular}

Description: VU = Very Unprepared; U = Unprepared, $\mathrm{R}=$ Ready, VR = Very Ready

The description of students' E-readiness data in participating in online biology learning is in Table 1 . These are then analyzed using the Mutula and Brakel, (2006) E-Readiness evaluation model. The evaluation model in question is An Integration Information Rich E-Readiness Assessment Tool which can be described as follows.

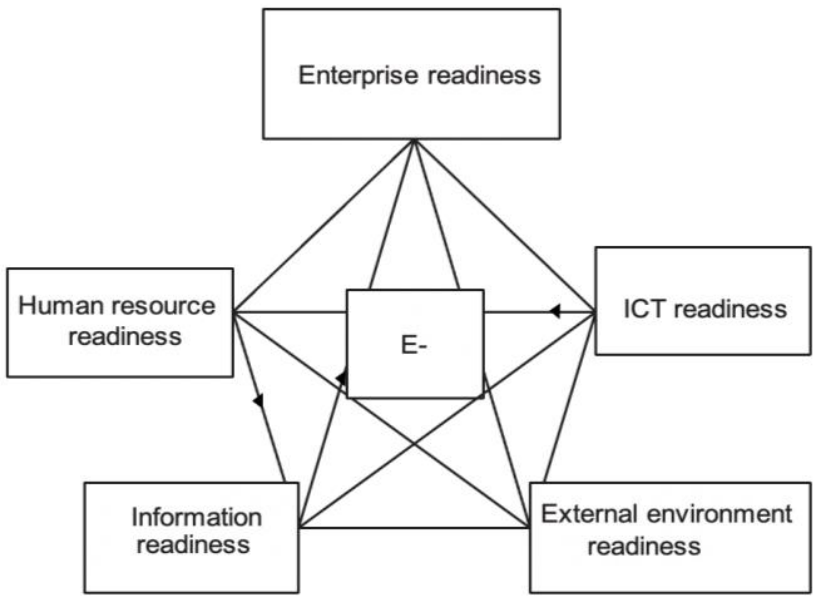

Figure 1. E-Readiness Evaluation Model (Mutula and Brakel, 2006)

The results of the data analysis obtained a description of the e-readiness profile of students learning biology online for each e-readiness indicator as follows.

\section{Enterprise Readiness Segment}

Enterprise Readiness Segment is the level of readiness of students in using information and communication technology applications in learning biology online. Enterprise readiness segment includes: (1) Students' readiness to seek information related to biology material to be studied through search engines such as Google, Yahoo, etc., or social media such as Whatsapp, Facebook, etc. before biology learning begins. The data shows that $1.3 \%$ of students are very unprepared, $8.8 \%$ of students are not ready, $63.5 \%$ of students are ready, and $26.4 \%$ of students are very ready. Based on these data, it was found that $89.9 \%$ of students who already have the ability to use information and communication technology applications in learning biology online have the ability to use information and communication technology applications; (2) Students who prefer to read books or other learning resources on their computers, laptops or cellphones are $10.8 \%$ of students who are very ready, $39.1 \%$ of students are not ready, $37 \%$ of students are ready, and $13.2 \%$ of students are very ready. From these data, it can be seen that $50.2 \%$ of students prefer to read books or other learning resources on computers, laptops 
or mobile phones; (3) The level of readiness of students in using e-learning to complete biology learning tasks is $2.1 \%$ of students are very unprepared, $11.6 \%$ of students are not ready, $61.9 \%$ of students are ready, and $24.4 \%$ of students are very ready. Based on these data, it shows that $86.3 \%$ of students are able to use e-learning to complete biology learning tasks; (4) The level of readiness of students to use their free time to study biology through cellphones, tablets, computers is $1.9 \%$ of students very unprepared, $16.4 \%$ of students not ready, $63.2 \%$ of students ready, and $18.5 \%$ of students very ready. The data shows that $81.7 \%$ of students use their free time to study biology through cellphones, tablets, or computers; (5) The ability level of parents or guardians to facilitate students in learning biology using information and communication technology (computers, laptops, cellphones, etc.) is 2.1 very unprepared, $6.6 \%$ not ready, 50.6\% ready, and $40.7 \%$ very prepared. This data shows that $91.3 \%$ of parents or guardians of students can facilitate students in learning biology using information and communication technology (computers, laptops, cellphones, etc.).

Based on the results of data analysis on the Enterprise Readiness Segment indicator, it was found that on average high school students in West Lombok already can utilize information and communication technology applications to study biology online with different levels of readiness. The level of student readiness in using information and communication technology applications in online biology learning is shown visually in Figure 2.

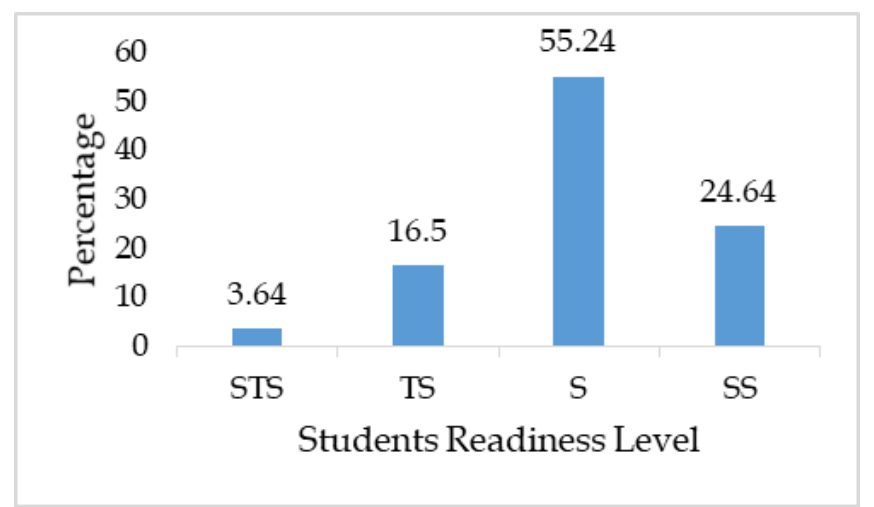

Figure 2. Student Enterprise Readiness Segment

\section{Information Communication and Technology Readiness Segment}

Information Communication and Technology readiness segment is the readiness of infrastructure and internet access. This readiness includes: (1). The level of readiness of students in searching for biology learning materials through the internet is $1.8 \%$ very unprepared, $5.9 \%$ not ready, $57.2 \%$ ready, and $35 \%$ very ready. The data shows that $93.2 \%$ of students can search for biology learning materials online via the internet; (2) The level of readiness of students about basic internet (email, searching, download) in accessing biology subject matter is $1.8 \%$ very unprepared, $12.5 \%$, not ready, $56.3 \%$ ready, and $29.4 \%$ very ready. The data shows that $85.7 \%$ of students who already have basic internet skills; (3) The ability of students to use social media to complete biology homework assignments is $3.5 \%$ very unprepared, $18.6 \%$ unprepared, $48.6 \%$ ready, and $29.3 \%$ very ready. This means that $77.9 \%$ of students can use social media in completing school assignments in biology subjects; (4) Students who can use online media to help them in studying biology are $2.7 \%$ very unprepared, $10 \%$ unprepared, $45.8 \%$ ready, and $41.5 \%$ very ready. This means that $87.3 \%$ of students can use online media to help them learn biology; (5) The ability of students to operate basic computers such as typing, creating, saving, editing files, etc. is $5.3 \%$ very unprepared, $23 \%$ not ready, $48.2 \%$ ready, and $23.5 \%$ very ready. The data shows that $71.7 \%$ of students have basic computer skills such as typing, creating, saving, and editing files, etc.

Based on the results of student ICT readiness data analysis, it can be stated that the readiness of infrastructure in accessing the internet is $82.96 \%$ of students are ready. From the results of the data analysis, it can be concluded that SMAN students in West Lombok have the readiness and ability to use infrastructure and internet access to study biology online. Visually, the level of infrastructure readiness and students' internet access can be seen in Figure 3.

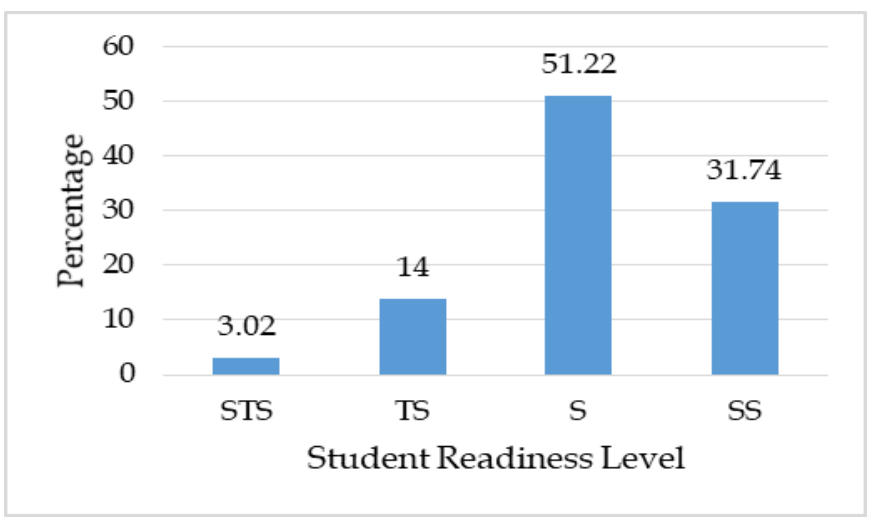

Figure 3. ICT Readiness Segment Students

\section{Human Resources Readiness}

Human Resources Readiness is the mastery of students' skills in using computers or gadgets for learning. This readiness consists of: (1) Students who already have an Android cellphone/tablet/computer that can be used to search for information or biology learning materials via the internet or social media with categories very unprepared $1.0 \%$, not ready $5.9 \%$, ready $60.6 \%$ and very ready $32.5 \%$. This shows that students 
who already have a computer or gadget for learning biology are 93.1\%; (2) Students who can access information related to biology learning materials anywhere are $1.3 \%$ very unprepared, $15.8 \%$ unprepared, $57.1 \%$ ready, and $25.9 \%$ very ready. The data shows that students who can access information about biology learning materials are $84 \%$; (3) The ability of students to follow developments and update social media and other applications to find information on the required biology subject matter is $1.4 \%$ very unprepared, $14.8 \%$ not ready, $66.6 \%$ ready, and $17.2 \%$ very ready. This data shows that the ability of students to follow developments and update their social media applications to find information on biology subject matter is $77 \%$; (4) The ability of students to rediscover information related to biology lessons that have been accessed from the internet is $1.4 \%$ very unprepared, $14.8 \%$ unprepared, $66.6 \%$ ready, and $17.2 \%$ very ready. This shows that the ability of students to rediscover information related to biology lessons that have been accessed from the internet is $83.8 \%$; (5) Students who have active information sharing facilities in cyberspace (Facebook, WhatsApp, blog, etc.) are $1.9 \%$ very unprepared, $15.6 \%$ not ready, $55.8 \%$ ready, and $26.7 \%$ very ready. From these data, it can be seen that students who have active information sharing facilities in cyberspace (Facebook, WhatsApp, blog, etc.) are $82.5 \%$.

Based on this information, it can be concluded that $83.88 \%$ of SMAN students in West Lombok already have skills in using computers or gadgets to take part in online biology lessons. Visually, the level of student readiness in using computers or gadgets to take part in biology learning can be seen in Figure 4.

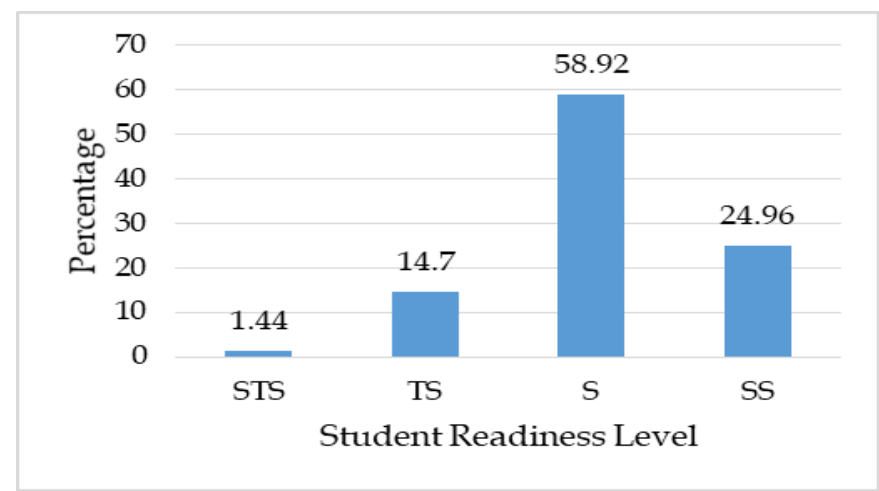

Figure 4. Human resources readiness of students

\section{Information Readiness Segment}

Information Readiness Segment is the readiness of students' knowledge to access information about learning materials. This ability relates to students' readiness in terms of students' readiness to use applications from the internet to view videos or simulations related to biology subject matter. The level of readiness was 0.6 very unprepared, $12.2 \%$ unprepared, $58.7 \%$ ready, and $28.5 \%$ very ready. From these data, it can be seen that the level of readiness of students' knowledge to access information related to biology learning materials is $12.8 \%$ not ready, and $87.2 \%$ ready. The level of readiness of students in collecting biology subject matter on their computers or cellphones is $2.1 \%$ very unprepared, $26.4 \%$ not ready, 58.8 ready, and 12.7 very ready. From these data, it can be seen that the level of readiness of students in collecting biology subject matter on their cellphones or computers is $28.5 \%$ not ready, and $71.5 \%$ of students are ready.

The level of readiness of students to have biology subject matter on social media is 2.7 very unprepared, $24.3 \%$ not ready, 59 ready, and $14 \%$ very ready. From this data, it can be seen that $73 \%$ of students who have biology subject matter stored on social media and $27 \%$ do not have it.

The student's readiness to use e-books as a means to study biology was $6.6 \%$ very unprepared, $33.9 \%$ unprepared, $48.4 \%$ ready, and $11.1 \%$ very ready. From these data, it can be seen that $40.5 \%$ of students have not been able to use e-books as a means of learning biology, and $59.5 \%$ of students have been able to use them. The student's readiness to provide Biology learning materials from e-books and e-learning was $7.2 \%$ very unprepared, $30.4 \%$ not ready, $50.2 \%$ ready, and $12.2 \%$ very ready. This readiness data shows that students who have the ability to provide biology learning materials from e-books and e-learning are $62.4 \%$, and $37.6 \%$ are not. Visually, the level of students' knowledge readiness to access information related to biology learning materials can be seen in Figure 5 .

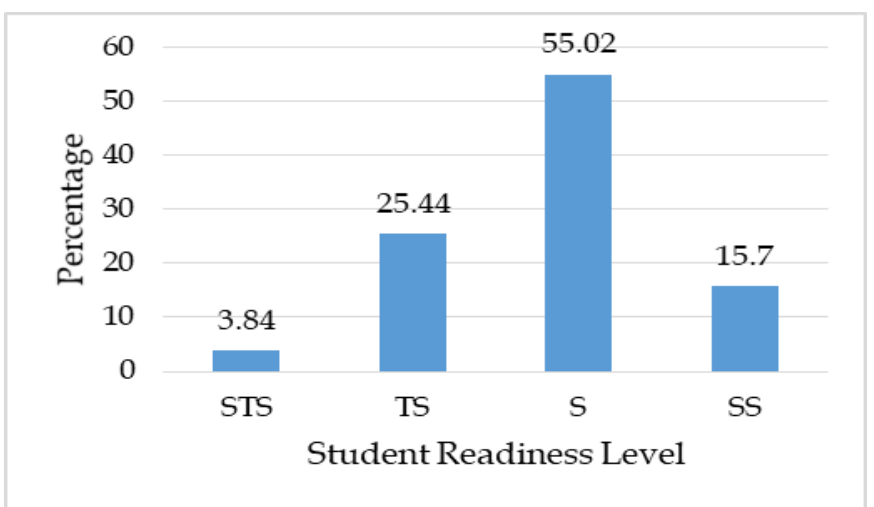

Figure 5. Student Information Readiness Segment

\section{External Environment Readiness Segment}

External Environment Readiness Segment is environmental support for the use of Information and Communication Technology by students. This segment includes students who have sufficient electricity 
networks to use to access information via the internet around their homes and schools, namely $3.2 \%$ very not enough, $15.9 \%$ not enough, $56.8 \%$ enough, and $24.1 \%$ more than enough. This means that $19.1 \%$ of students do not have enough electricity that can be used to access information about biology subject matter, and 81.9 have sufficient electrical power for activities to access information related to biology subject matter.

Students' opinions about the readiness of educators to use social media in providing information about biology subject matter are $0.8 \%$ very unprepared, $5.5 \%$ not ready, $58.7 \%$ ready, and $35 \%$ very ready. This data shows that according to students' views there are still educators who are not ready to use social media to convey information about biology subject matter 6.3\%, and $93.7 \%$ who are ready to use social media to support online learning activities.

The use of ICT for biology learning activities by educators is $2.1 \%$ very unprepared, $10.1 \%$ unprepared, $63.3 \%$ ready, and $24.3 \%$ very ready. This data illustrates that $85.8 \%$ of educators are ready to use ICT for online learning activities, and $12.2 \%$ have not used IC optimally for learning.

School support to provide internet network in the school environment $3.5 \%$ are not ready to support, $10.5 \%$ are not ready to support, $43.7 \%$ are ready to support, and $42.3 \%$ are very ready to support. This means that according to students' opinion, the level of readiness of school support in providing internet access is $86 \%$ ready to support and $14 \%$ not ready. The speed of internet access owned by the school and owned by the students according to the students' opinion was $6.2 \%$ very bad, $20.1 \%$ not good, $47.7 \%$ good, and $26 \%$ very good. The information shows that in online learning $26.3 \%$ of students experience problems in accessing the internet, and $73.7 \%$ of students have good internet access to support online biology learning activities. Visually, the level of readiness of the internet network owned by students to access information related to biology subject matter can be seen in Figure 6.

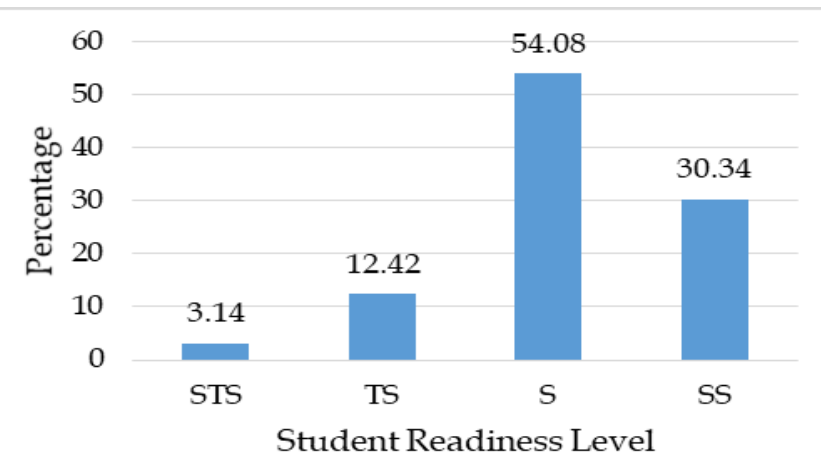

Figure 6. External Environment Readiness Segment of High School Students in West Lombok

\section{Conclusion}

The results of the analysis for each indicator of the E-readiness of students learning biology show that on average, the indicators of E-readiness in learning the biology of students are in the ready category. The percentage of E-readiness learning biology students on each indicator is Enterprise Readiness Segment 79.9\%, ICT readiness segment $82.96 \%$, Human resources readiness Segment $83.88 \%$, Information readiness segment $62.4 \%$, and External environment readiness segment $73.7 \%$. From the results of the research data analysis, it was found that an average of $80.5 \%$ of students' E-Readiness to learn biology had a good level of readiness, and $19.5 \%$ did not yet have a fairly good level of readiness in participating in online biology learning in West Lombok Regency.

\section{Acknowledgments}

The authors would like to express their deepest gratitude to the Rector of the University of Mataram who has facilitated the implementation of this research by providing research funds. We also thank all those who have assisted in carrying out this research.

\section{References}

Djalante, R., Lassa, J., Setiamarga, D., Sudjatma, A., Indrawan, M., Haryanto, B., Mahfud, C., Sinapoy, M. S., Djalante, S., Rafliana, I., Gunawan, L. A., Surtiari, G., \& Warsilah, H. (2020). Review and analysis of current responses to COVID-19 in Indonesia: Period of January to March 2020. Progress in disaster science, 6, 100091. https://doi.org/10.1016/j.pdisas.2020.100091

Handarini, O.I. \& Wulandari, S.S., 2020. Pembelajaran Daring Sebagai Upaya Study From Home (SFH) Selama Pandemi Covid 19. Jurnal Pendidikan Administrasi Perkantoran (JPAP) 8 3: 496-503. Retrieved https://journal.unesa.ac.id/index.php/jpap [Indonesian]

Hidayat, S., Hendrayana, A., \& Pujiastuti, H. (2018). Identification of Readiness of Developing University to Apply Information and Communication Technology (ICT) in Teaching and Learning. SHS Web of Conferences, 42, 117. https://doi.org/10.1051/shsconf/20184200117

Laksana, S. (2021). Post Pandemic Indonesian Regional Development Planning, New Normal, New Orientation: The Case of West Java. Jurnal Perencanaan Pembangunan: The ..., V(1), 32-50. https://doi.org/10.36574/ipp.v5i1.150 
1-Hanawi, M. K., Angawi, K., Alshareef, N., Qattan, A. M. N., Helmy, H. Z., Abudawood, Y., Alqurashi, M., Kattan, W. M., Kadasah, N. A., Chirwa, G. C., \& Alsharqi, O. (2020). Knowledge, Attitude and Practice Toward COVID-19 Among the Public in the Kingdom of Saudi Arabia: A Cross-Sectional Study. Frontiers in Public Health, 8, 217. https://doi.org/10.3389/fpubh.2020.00217

Muthuprasad, T., Aiswarya, S., Aditya, K. S., \& Jha, G. K. (2021). Students' perception and preference for online education in India during COVID -19 pandemic. Social Sciences \& Humanities Open, 3(1), 100101.

https://doi.org/https://doi.org/10.1016/j.ssaho .2020 .100101

Mutula, S., \& Brakel, P. (2006). An evaluation of ereadiness assessment tools with respect to information access: Towards an integrated information rich tool. International Journal of Information Management, 26, 212-223. https://doi.org/10.1016/j.ijinfomgt.2006.02.004

OECD. (2020). The impact of COVID-19 on student equity and inclusion: supporting vulnerable students during school closures and school reopenings. OECD Publishing, 1-37. Retrieved from:

https://www.oecd.org/coronavirus/policyresponses...d593b5c8/

Ratnawati, D., \& Vivianti, (2020). Persepsi Mahasiswa Terhadap Pembelajaran Daring pada Matakuliah Praktik Aplikasi Teknologi Informasi. JEE Jurnal Edukasi Elektro, 4(2): page 110 - 120. Retrieved From: https://journal.uny.ac.id/index.php/jee [Indonesian]

Sadikin, A., \& Hamidah, A. (2020). Pembelajaran Daring di Tengah Wabah Covid-19. BIODIK, 6, 109-119. https://doi.org/10.22437/bio.v6i2.9759 [Indonesian]

Sagita, M., \& Khairunnisa, K. (2020). E-Learning for Educators in Digital Era 4.0. Budapest International Research and Critics Institute (BIRCIJournal): Humanities and Social Sciences, 3(2), 1297 1302. https:// doi.org/10.33258/birci.v3i2.974

Sohrabi, C., Alsafi, Z., O'Neil, N., Khan, M., Kerwan, A., Al-Jabir, A., Aghad, R. 2020. World Health Organization declares global emergency: A review of the 2019 novel coronavirus (COVID19). International Journal of Surgery, 76, 71-76. doi: https://doi.org/10.1016/j.ijsu.2020.02.034

Syarifudin. A.S. (2020). Impelementasi Pembelajaran Daring Untuk Meningkatkan Mutu Pendidikan Sebagai Dampak Diterapkannya Social Distancing. Jurnal Pendidikan Bahasa dan Sastra Indonesia Metalingua, 5(1): 31-34. doi: https://doi.org/10.21107/metalingua.v5i1.7072 [Indonesian]

The Ministry of Education and Culture. (2020): Kebijakan Kemendikbud di Masa Pandemi. Kemendikbud: Jakarta. Dirjen GTK. Retrivied from https://gtk.kemdikbud.go.id/readnews/kebijakan-kemendikbud-di-masa-pandemi [Indonesian]

Yuhdi, A., \& Amalia, N., (2018) Desain Media Pembelajaran Berbasis Daring Memanfaatkan Portal Schoology pada Pembelajaran Apresiasi Sastra. Jurnal Basastra 7(1): 14-22 doi: https://doi.org/10.24114/bss.v7i1.9320 [Indonesian] 